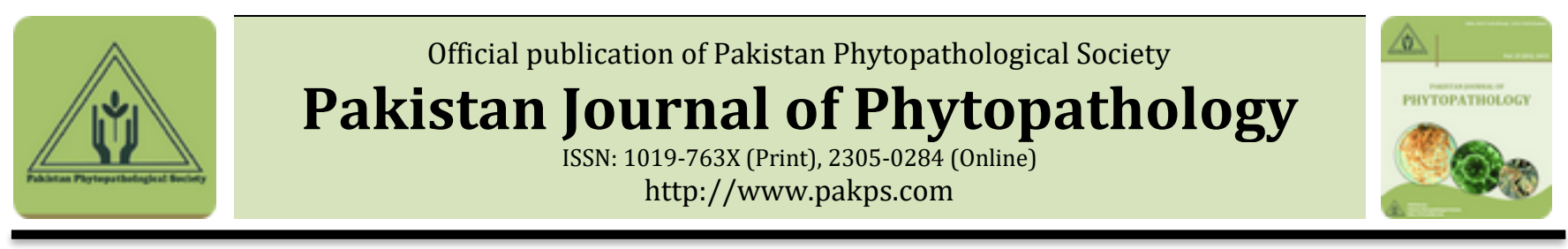

\title{
FIELD STUDY ON INTEGRATED DISEASE MANAGEMENT OF CABBAGE HEAD ROT CAUSED SCLEROTINIA SCLEROTIORUM
}

\author{
Muhammad U. Yasin*, Saba Saeed, Saima Naseer
}

Ayyub Agricultural Research Institute, Faisalabad, Pakistan.

\begin{abstract}
A B S T R A C T
Cabbage head rot caused by fungi Sclerotinia sclerotiorum is a very common problem for vegetable growing farmers. Diseased stem and leaves produce white cottony growth and hard sclerotia. Cabbage is used as fresh green salads thus disease management is not safe and economical by using solely chemical therapy. An integrated approach was designed in 4 years trial evaluation to minimize disease incidence. In first step best treatments were selected by using methods of in-vitro food poison evaluation method, cultural management, soil fumigation and foliar treatments by botanical extracts and modern fungicides. Cultural practices included north south row orientation, crop sanitation by elevated ridges, and humidity management by adjusting irrigation schedule showed control of up to $15 \%$. Soil fumigation by Thiophenate Methyle and score reduced disease incidence by 50.33\%. Among the five bio-extracts foliar application of jatropha extract showed best control of 31\%. From four fungicides Amistar Top showed highest control of $73 \%$ in 2018 and Score produced best results of $76 \%$ in 2019 . In second step best treatments were combined in a single application integrated strategy which reduced incidence by $80.5 \%$. Farmers were advised to adopt safe methods keeping in mind the extant of disease incidence and crop loss.
\end{abstract}

Keywords: Integrated Disease Management, Cabbage, Cultural control, Sclerotinia sclerotiorum

\section{INTRODUCTION}

Cabbage (Brassica oleracea L. var capiata) of brassica family, is economically important agricultural crop which is grown throughout the world (Singh et al., 2010). It is highly nutritious vegetable, used in animal fodder sauerkraut, slaw and most often in food dishes (Fang et al., 2005). It improves digestive process in stomach and reduces constipation and cancer incidence Jiao et al. (2010). In Pakistan it is grown as Rabi vegetable and has become a leading vegetable which is cooked in dishes and used extensively in salads. In recent years its cultivation has increased from 3000 ha to 5000 ha (Govt. of Pakistan, 2016). Its average house hold consumption is $3.5 \mathrm{~kg}$ per month in Pakistan (Fayaz et al., 2014) but its yield is not as high as in other

Submitted: August 15, 2020
Revised: December 08, 2020
Accepted for Publication: December 22, 2020
* Corresponding Author:
Email: aropp2017@gmail.com
(C) 2017 Pak. J. Phytopathol. All rights reserved.

cabbage countries specially in case of seed crop due to attack of diseases and pests. The most common quality and yield limiting factor in cabbage is its head rot disease caused by Sclerotinia sclerotiorum (Loganathan et al., 2010) It was first reported in: New York (Dillard and Hunter, 1986), North Carolina (Cubeta et al., 1997), in Texas (French and Schultz, 2009) and New Zeland(Jones et al., 2014). In Mexico, Sanogo et al. (2015) isolated S. sclerotiorum from grown rotted cabbage leaves and confirmed it through using PCR technique. Mahalingam et al. (2016) found S. sclerotiorum causing head rot of cabbage during a survey in Sri Lanka and verified the pathogen through PCR amplification of its rDNA region using ITS1 and ITS primers. S. sclerotiorum as the pathogen causing head rot of cabbage was confirmed for the first time in Pakistan by (Mirza and Ahmad, 1988) from the cabbage samples found from field of NARC Islamabad.

The fungus $S$. sclerotiorum is a nonspecific plant pathogen with a broad host range (Saharan and Mehta, 
2008), infects more than 400 plant species (Boland and Hall 1994). It produces only sexual ascospore but no asexual spore. Its pathogenicity factors involve enzymes that degrades cell wall and Oxalic Acid, mycelia virulence decreases with its age (Wang et al., 2016). In cabbage it causes severe losses to crops in field, to produce in storage, transport and market processes (Dillard and Hunter, 1986). It can survive long time in soil as sclerotia (Adams and Ayers 1979; Willetts and Wong 1980), in favorable conditions its sporulation attack the leaves in contact with soil (McLean, 1958). Early symptoms include white spots on stalk, a soft rot develops with characteristic symptom of luxuriant white cottony mycelium with enlargement of water soaked lesions affecting entire head or leaf layers and black hard and large sclerotia forms in the head (Sherf and MacNab, 1986). The whole plant wilts and topples by collapsing stem near the soil, pathogen invades pith to cause death prior to production of seeds (Hoes and Huang, 1975). The fungus grows and transmits to other crop plants causing severe damage to yield and quality of cabbage crop (French and Schultz, 2009).

Control of head rot of cabbage has remained a serious concern in Pakistan for large and medium field farmers. No variety of Brassica oleracea $L$. var capiata yet provides significant resistance against $S$. sclerotiorum (Dickson and Petzoldt, 1994; Hudyncia et al., 2000; Mahalingam et al., 2017). For this soil born fungus, cultural practices such as weed eradication and crop rotation did not served the purpose for complete control because of pathogen's wide host range coupled with its ability to survive in the soil for long times (Adams and Ayers 1979; Willetts and Wong 1980). S. sclerotiorum can survive as sclerotia in soil up to ten years thus one year of crop rotation is not enough to survive pathogen attack when conditions become favorable. It's control through cultural practices is not sufficient and effective in favorable conditions (Young and Werner, 2012). Biological control of S.sclerotiorum of cabbage with trichoderma, chitin based (Loganathan et al., 2010) and Coniothyrium minitans with Trichoderma spp. has shown some potential on experimental basis pots in lab (Jones et al., 2014). But these products require mass multiplication for field application and are not easily available yet in market as commercial products (Loganathan et al., 2010); thus there practice in field is not adapted and neither there application proved economical for commercial cabbage growers.

Disease caused by $S$. sclerotiorum is not managed consistently and economically in field due to their ability to with stand the adverse environmental conditions and sporulation on arrival of favorable environmental conditions. Rather than relying on single control strategy combined measures have to be applied for management. (Mila et al., 2003). It has become very well understood fact now different methods must be combined for maximum control of $S$. sclerotiorum disease into a single management program. (Saharan and Mehta, 2008). Integrated disease management (IDM) is a technique of combining range of best possible measures and involves the use of all disease management approaches practically available to farmers which can include cultural, biological and chemical methods with aim of keeping disease incidence lower than economic threshold levels.

Cultural practices can be modified to maintain low level of humidity to minimize leaf injury in cabbage field as duration of humidity is an important factor for disease development by S. sclerotiorum (Tores and Moreno, 1991). Dry weather conditions reduce cabbage white mold development caused by S. sclerotiorum (Dillard et al., 2004). Flooding schedule in which a field is continuously flooded in 23-45 days cycles of alternate flooding and drying led to destruction of sclerotia of $S$. sclerotiorum and reduced disease in Florida and India (Singh and Tripathi, 1996).

Soil chemical treatment is very important to reduce pathogen pressure. If left untreated S. sclerotiorum can survive in soil in form of sclerotia for ten years which reduces the effectiveness of technique of crop rotation for management of white mold (Young and Werner, 2012). Alabouvette and Louvet (1973) effectively used methye bromide and formaldehyde in pre-plant treatments to destroy sclerotia in the soil. Sclerotinia can be controlled effectively by soil fumigation in tobacco by Benomyl and thiophanate-methyle (Hartill and Campbell, 1973). Carbendazim controlled sclerotinia rot in peas when applied in the soil before sowing of pea s (Sugha, 1999).

Chemical control is used only when it is necessary when disease incidence climbs to economic threshold levels in the way so it can only cause least disruption for natural mechanisms involve in vegetable 
consumers, harvesting and handling personal and environment because it is harvested in several pickings by manual method. IDM technique, do not eliminate chemical therapy for control but it allows judicious use of fungicides by safe and wise decision making principles. Razdan and Sabitha (2009)

Fungicides are routinely applied to eradicate fungal spores, reduce its germination potential, to check its mycelium development and to break its disease cycle (Turkington and Morrall, 1993). But no fungicide has yet been registered specifically for control of white mold or head rot of cabbage. Lack of a registered fungicide, non-availability of completely resistant varieties and sporadic occurrence of this disease on large commercial farms has made its management very difficult (Hudyncia et al., 2000). Thus there is a dire need to identify relatively safe chemicals for its control. Hence the present study was focused to evaluate most suitable cultural methods, soil treatments along with modern foliar fungicides that can be safely used against S. sclerotiorum for complete control of cabbage head rot.

\section{MATERIAL AND METHODS}

Field experimental trial was conducted in Rabi 201718, Rabi 2018-19 and Rabi 2019-20 in the field of Plant Pathology Research Institute where 85\% cabbage mortality was recorded previous year. Purpose of trial was to devise an integrated approach for farmers and to evaluate the suitable cultural practices, efficacy of plant extracts and fungicides for lowering disease incidence and yield losses. Seed of variety "Golden Acre" in Punjab was obtained from the Vegetable research institute, Faisalabad. Four separate trials were conducted for in-vitro, Cultural, Bio-extract and Fungicidal management of cabbage head rot. Cabbage seeds for nursery plants were sown in $2^{\text {nd }}$ week of October and plants were transplanted in $1^{\text {st }}$ week of November in open field in rows with planting distance $60 \mathrm{~cm}$ between rows and $40 \mathrm{~cm}$ within plants as described by Jensen et al. (2005). Soil type was sandy loam and after thinning number of plants retained in each row was 20 Insect control and fertilizer applications were carried out in field according to local practices. Urea, $46 \%$ was applied thrice during growing season at a rate of $100 \mathrm{~kg} \mathrm{ha}^{-1}$ in experimental field. To control insects Acelam 26\% WDG (Acetamiprid 23.5\% + Lambda Cyhalothrin 2.5\%) at rate of $60 \mathrm{~g} \mathrm{ha}^{-1}$ was sprayed before inoculating crop with fungus. Trial was laid out in Randomized Complete Block Design with 3 replications having area of $14 \mathrm{~m} \times 9 \mathrm{~m}$ each.

Isolation and multiplication: Diseased samples of cabbage head rot were collected from different farmer fields and were brought to lab. Leaves with prominent symptoms were cut into $5 \mathrm{~mm}$ small pieces, surface sterilized with $0.5 \%$ solution of sodium hypochlorite. These were placed in $90 \mathrm{~mm}$ petri plates already poured with PDA media and dishes were placed in temperature of $25^{\circ} \mathrm{C}$. After 3 days fungal colony of $S$. sclerotiorum was visible with white mycelium and culture was transferred to another PDA plate for purification, where black hard structures surrounded with crystal shaped clestothecia started to develop on white fungal colonies which became sclerotia of $2 \mathrm{~mm}$ with irregular shape.

In vitro Evaluation of Fungicides: For in vitro efficacy of fungicides Potato Dextrose Agar media was prepared by adding four fungicides at 0.001 PPM concentration at $45^{\circ} \mathrm{C}$, media was poured in Petri dishes and $5 \mathrm{~mm}$ inoculum disc of $S$. sclerotiorum culture was placed in center according to method of Dalili et al. (2015) with three replications. Plates were incubated at $22^{\circ} \mathrm{C}$ and results were noted after four days for fungal growth inhibition by fungicides according to Pandey et al. (1982).

Field Multiplication of inoculum: For the purpose of mass multiplication in field $2 \mathrm{~kg}$ chickpea were boiled for 30 minutes on $90^{\circ} \mathrm{C}$ and then dried for 20 minutes by spreading on paper. Transparent plastic bags were filled with $0.2 \mathrm{~kg}$ of grams and were sealed with cotton by placing cork plug; these bags were autoclaved at $121^{\circ} \mathrm{C}$ to kill all micro-organisms. Fungal culture of $6 \mathrm{~mm}$ size were inoculated in those bags and were place on $30^{\circ}$ for 10 days, whitish cottony fungal colony was fully developed on grams. These were mashed and spread in each replication in field near stems of three week old crop plants selecting a day with light precipitation of rain. Field was irrigated on alternate days for two weeks to promote growth and infection of fungus, on every evening water was also misted on all floral parts of plants to maintain moist conditions, cool wet weather in fall supports head rot development in cabbage (Hudyncia et al., 2000). Symptoms started to develop on $5^{\text {th }}$ day of inoculation on lower stem in form of cottony white mycelium formation.

Cultural Practices: Cultural practices such as moisture 
regulation and field sanitation can be modified to reduce moistness and extend dry period in cabbage grown fields. Thus effect of height of furrows and Time of irrigation was evaluated. Furrows were made north and south facing as reported by Bennett and Elliot (1972) incidence and severity of sclerotinia damage can be reduced by adopting north and south facing row orientation. DI\% was compared for furrow height of 7 inches with 5 inches and DI\% of morning irrigation time with evening irrigation time. First treatment was 7" furrow with evening irrigation, second treatment was 5" furrow with Evening irrigation, and third treatment was 5" furrow with Morning irrigation, while fourth treatment was 7" with morning irrigation. Disease incidence was calculated by $D I \%$ formula.

Soil Treatment: Thus field area was flooded by adding chemicals in irrigation water before transplanting nursery to destroy fungal sclerotia. Five chemicals tested were Carbandazim 500gm/ha, Topsin M $500 \mathrm{gm} / \mathrm{ha}$, Score $750 \mathrm{ml} / \mathrm{ha}$, Alliete $1 \mathrm{Kg} / \mathrm{ha}$, Topsin M $500 \mathrm{gm} / \mathrm{ha}+$ Score $750 \mathrm{ml} / \mathrm{ha}$. And no chemical was added in control treatment. DI\% was calculated each year by formula after comparing incidence in treated with untreated control.

Foliar Application of Chemicals and Plant Extracts: In cabbage crop cultural practices prevents disease development to some extent but most effective method found for control of S. sclerotiorum is chemical application (Mahalingam et al., 2017). Five chemical treatments viz Nativo 75\%WG (Tebuconazole + Trifloxystrobin) @ 0.50gm/liter, Score 250EC (Difenoconazole) @ 0.125ml/liter, Kocide 3000 52.4\%WG (Copper Hydroxide) @ $0.25 \mathrm{gm} /$ liter, Amistar Top 325SC (Azoxystrobin + Difenoconazole)@0.30 gm/liter were sprayed on foliar parts by using manually operated knapsack sprayer. First foliar spray was applied on the onset of disease and was repeated after two weeks.

Five plant extracts Tovacco, Neem, Clove, Jatropha and Garlic were used for the control of $S$. Sclerotiorum. Disease incidence and inhibition was calculated each year by formulas after comparing $D I \%$ in treated with untreated control rows. While in control treatment plants were sprayed with water only.

Combining best treatments for IDM approach: Three treatments with replication were used in 2020 trial by combining best control treatments from previous years to evaluate integrated disease management strategy for Cabbage Head Rot. First combination was flooding field with Score $750 \mathrm{ml} /$ ha + Topsin M 500gm/ha field with irrigated in morning, inoculum was spread in field by infected grams method, on appearance of first symptom Score was sprayed on foliar parts @ $0.125 \mathrm{ml} / \mathrm{lit}$ of water. In second treatment Jatropha extract was sprayed on foliar parts with all other combination of first treatment. In third treatment no chemical was flooded neither was applied on foliar part with morning time irrigation. DI\% was calculated by using formula and disease reduction was compared with untreated control.

Data Recording: There were five treatments and each treatment had 80 plants in each replication and 240 plants in 3 treatments. All the chemical treatments were sprayed twice in Randomized Completely Block Design (RCBD). Head rot Incidence was expressed by percent disease index (PI) was calculated after heading stage (Loganathan et al., 2010) by using formula:

$$
\text { Disease incidence }(\%)=\frac{\text { No. of infected plants }}{\text { Total no. of plants }} \times 10
$$

Disease reduction over control was calculated after final spray by using the formula;

$$
\text { Disease reduction over control }(\%)=\frac{\text { Control }- \text { Treated }}{\text { Control }} \times 100
$$

\section{RESULTS AND DISCUSSION}

The results were analysed statistically by analysis of variance and means were separated using least significant differences (L.S.D) test by using Statistix 8.1 software.

In vitro Evaluation of Fungicides: Efficacy of four fungicides at viz. Nativo, Score, Kocide, Amistar Top was checked by food poison method while comparing means of mycelial growth in chemical added PDA plates to means in simple untreated PDA plates. All fungicides showed significant response in control fungal growth. Amistar Top and score shared same levels of significance while Amistar Top showed maximum fungal growth inhibition $98.48 \%$ whereas Kocide showed minimum growth inhibition $80.23 \%$. Table shows means of mycelial growth in PDA made with fungicides. 
Table 1. Mycelial growth(MMG) of Sclerotinia Sclerotiorum and inhibition \% in petri plates by food poison method.

\begin{tabular}{lll}
\hline & Food Poison Method 2017 \\
\hline & MMG (mm) & $\begin{array}{l}\text { Growth } \\
\text { inhibition (\%) }\end{array}$ \\
\hline Nativo & $4.67 \mathrm{C}$ & 94.68 \\
\hline Score & $3.00 \mathrm{CD}$ & 96.58 \\
\hline Kocide & $17.33 \mathrm{~B}$ & 80.23 \\
\hline Amistar Top & $1.33 \mathrm{D}$ & 98.48 \\
\hline Control & 87.67 A & \\
\hline
\end{tabular}

Cultural Practices: Cultural practices can play important role in controlling disease losses thus DI (\%) was checked while keeping the crop untreated by any soil and foliar chemical. DI (\%) was greater at 5" furrows, cabbage leaves got more in contact with ground and irrigation water resulting caused leaf injuries that increased ingression of $S$. Sclerotiorum Dillard and Cobb (1995). DI\% differed significantly in morning and evening irrigated fields. Morning irrigated field showed less DI (\%) when compared with evening irrigated crop due to extended moist period was extended in the evening irrigation, as infection process is favored by cool and moist conditions of leaf wetness for 16 hours (French and Schultz, 2009). Table shows DI (\%) on different furrow height and irrigation during the year of 2018 and 2019. Results showed that timing of irrigation is more important than height of furrows.

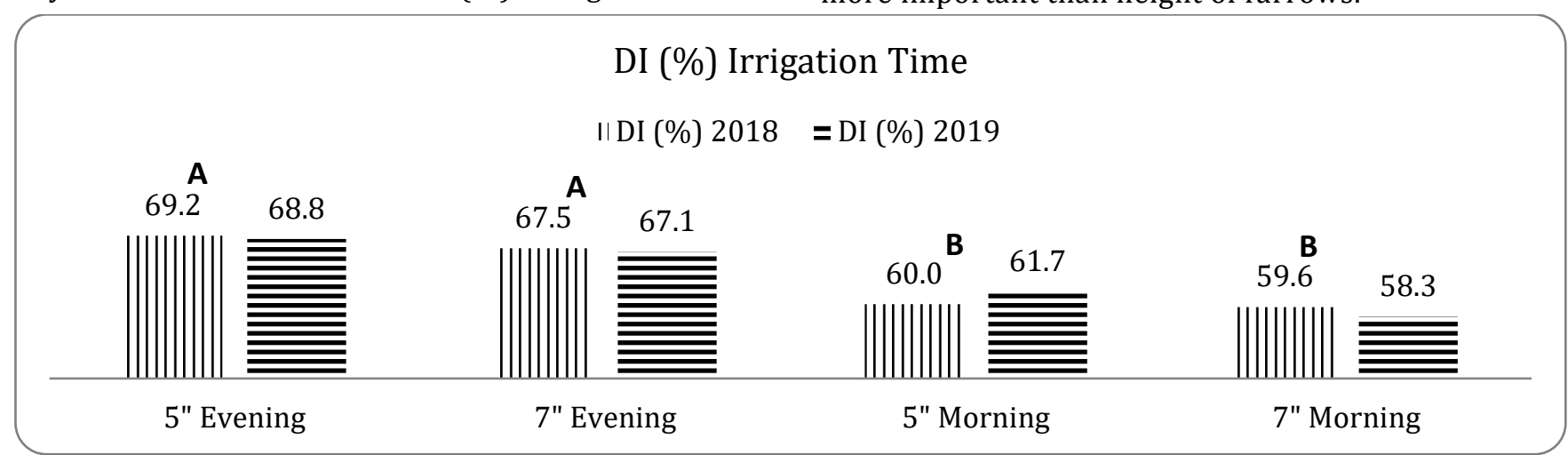

Figure 1. Bar diagram shows DI\% for morning and evening irrigated crops. Vertical Pattern shows DI\% for the year of 2018 while Horizontal Pattern shows data for the year of 2019.

Soil chemical Treatment: Six soil treatments were years when compared with control treatment. tested in isolation for control of cabbage White Mold Fungicides inhibit the sporulation of fungal sclerotia without applying any foliar application. Score + Topsin present in soil thus lower the disease incidence by M showed maximum disease reduction of $51 \%$ for both decreasing soil inoculum pressure.

Table 2. Disease incidence \% and disease reduction \% by soil chemical treatment method for the year of 2018 and 2019.

\begin{tabular}{|c|c|c|c|}
\hline \multirow[t]{2}{*}{ Treatment } & \multicolumn{2}{|r|}{2018} & 2019 \\
\hline & DI (\%) & Decrease Reduction (\%) & Decrease Reduction (\%) \\
\hline Score + Topsin M & $29.58 \mathrm{E}$ & 51.70 & $31.25 \mathrm{D}$ \\
\hline Score & $33.75 \mathrm{D}$ & 44.90 & 44.37 \\
\hline Carbendazim & $39.58 \mathrm{BC}$ & 35.37 & $43.33 \mathrm{~B}$ \\
\hline Topsin M & $36.25 \mathrm{CD}$ & 40.82 & \multirow{2}{*}{$\frac{36.67 \mathrm{CD}}{38.33 \mathrm{BC}}$} \\
\hline Aliette & $40 \mathrm{~B}$ & 34.69 & \\
\hline Control & \multicolumn{2}{|l|}{$61.25 \mathrm{~A}$} & $62.92 \mathrm{~A}$ \\
\hline \multicolumn{4}{|c|}{$\begin{array}{lll}\text { Foliar Application of Chemicals and Bio-extracts: } & \text { When mean values of chemical treatments were } \\
\text { From four chemical treatments Amistar Top showed } & \begin{array}{l}\text { compared with control by applying LSD test, all } \\
\text { maximum disease reduction in 2018, while Score }\end{array} \text { treatments showed significant response while Amistar } \\
\text { showed maximum disease reduction in 2019. Among } & \text { Top and Score showed same level of significance among } \\
\text { chemicals minimum control was shown by Kocid of 50\% } & \text { foliar chemicals. From bio-extracts, Jatropha showed } \\
\text { and 57\% in } 2018 \text { and } 2019 \text { respectively. From the Bio- } & \text { maximum disease control of } 32 \% \text {, while tobacco extract } \\
\text { extracts Jatropha extract showed maximum disease } & \text { showed minimum control of } 14 \% \text { and } 10 \% \text { and } 2018 \\
\text { control of } 32 \% \text { and } 30 \% \text { in } 2018 \text { and } 2019 \text { respectively. } & \text { and } 2019 \text { respectively. }\end{array}$} \\
\hline
\end{tabular}


Table 3. Disease incidence $\%$ and control\% for chemical and bio-extracts for the year of 2018 and 2019. Treatments sharing same letters have same level of significance.

\begin{tabular}{|c|c|c|c|c|}
\hline \multicolumn{5}{|c|}{ Foliar Treatment Comparison } \\
\hline \multirow{2}{*}{ Treatment } & \multicolumn{2}{|c|}{2018} & \multicolumn{2}{|r|}{2019} \\
\hline & DI (\%) & Control (\%) & DI (\%) & Control (\%) \\
\hline Kocide & $31.25 \mathrm{~F}$ & 50 & $27.5 \mathrm{~F}$ & 57.42 \\
\hline Nativo & $25 \mathrm{G}$ & 60 & $23.33 \mathrm{G}$ & 63.87 \\
\hline Score & $17.08 \mathrm{H}$ & 72 & $15 \mathrm{H}$ & 76.77 \\
\hline Amistar Top & $16.6 \mathrm{H}$ & 73.44 & $15.42 \mathrm{H}$ & 76.13 \\
\hline Tobacco & $57.92 \mathrm{~B}$ & 14.20 & $57.92 \mathrm{~B}$ & 10.32 \\
\hline Garlic & $55.83 \mathrm{BC}$ & 17.28 & $54.58 \mathrm{BC}$ & 15.48 \\
\hline Clove & $52.92 \mathrm{CD}$ & 21.60 & $51.67 \mathrm{CD}$ & 20 \\
\hline Neem & $50.83 \mathrm{D}$ & 24.69 & $49.58 \mathrm{D}$ & 23.23 \\
\hline Jatropha & $45.83 \mathrm{E}$ & 32.10 & $45 \mathrm{E}$ & 30.32 \\
\hline Control & $67.5 \mathrm{~A}$ & & $64.58 \mathrm{~A}$ & \\
\hline
\end{tabular}

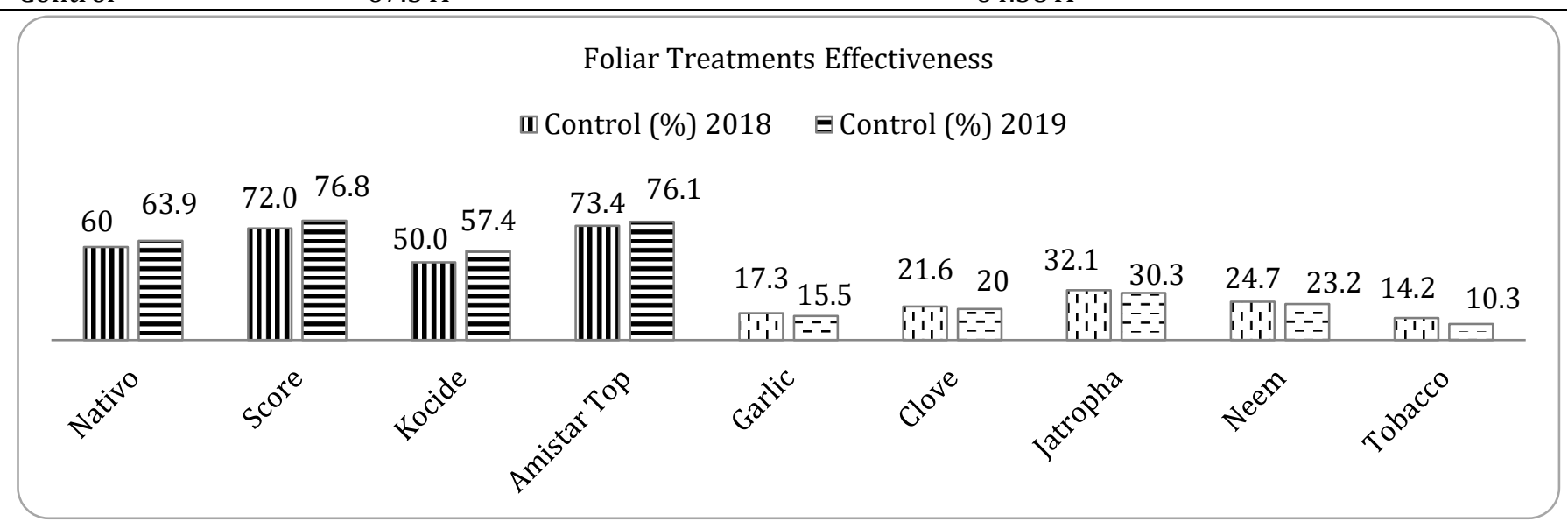

Figure 2. Bar diagram shows disease reduction \% of fungicides in line pattern and bio-extracts in dotted pattern. Vertical patterns show data of 2018 and horizontal shows data of 2019.

Combining Treatments for IDM: Treatments shown combination and Disease Reduction is mentioned in good results in previous years were applied in single table 5.

Table 4. DI\% and effectiveness of treatments applied in combination for Integrated Disease Management in Rabi 2019-20.

\begin{tabular}{lll}
\hline Treatment & Disease Incidence (\%) & Reduction in Disease incidence (\%) \\
\hline T1 (Morning Irri + Score + Flood Score + TopsinM & $12.08 \mathrm{C}$ & 80.54 \\
\hline T2 (Morning Irri + Jatropha + Flooding Score + Topsin) & $19.58 \mathrm{~B}$ & 68.46 \\
\hline Control & $60.08 \mathrm{~A}$ & \\
\hline
\end{tabular}

In T1 soil was treated with Score + Topsin M, crop was weekly irrigated on morning, score was applied as foliar fungicide.

In T2 soil was treated with Score + Topsin M, crop was irrigated in morning, Jatropha extract was applied as foliar application. T1 showed $80 \%$ control and $\mathrm{T} 2$ showed $68 \%$ control.

\section{CONCLUSION}

Single strategy management approach for control of diseases found in largely sown crops was less efficient and less economical. Rapidly emerging phenomenon of pathogenic resistance and rapidly changing environmental conditions in Pakistan have made it necessary to adapt techniques which combine a variety of control measures in single strategy. Although disease management by applying foliar chemicals is very popular and reliable approach, but chemicals pose environmental hazards residual effect of chemicals is most important concern in vegetables especially in salads and leafy vegetables like cabbage in which green leaves are consumed directly without further boiling and cocking. Thus finding a safe chemical to control head rot was biggest challenge along with its efficacy. Hou et al. (2016) studied residual effect of azoxystrobin in cabbage under field conditions and found that it is safe for 
cabbage disease control as it was dissipated rapidly with the mean half-live of 0.4 days at three geographical experiments, its terminal residues in cabbage at harvest time were below the maximum residue limit (MRL, 5mg $\mathrm{kg}^{-1}$ for azoxystrobin) established by Codex Alimentarius Commision.

Difenoconazole is another systemic fungicide with IUPAC name: 1-(2-[4-(4-chlorophenoxy)-2-chlorphenyl]4-methyl-1, 3-dioxolan-2-yl methyl]-1 H-1,2,4-triazole, it is very effective to control white mold caused by Sclerotinia sclerotiorum (Pandey et al., 2012).

Pathogens evolve resistance against fungicides when they are applied frequently and non-judiciously, improper fungicidal applications lead to development of fungicide resistant isolates. Mahalingam et al. (2017) found sclerotinia sclerotiorum isolates from cabbage that were resistant against Tubeconazole (Nativo) thus reducing its efficacy against head rot disease. Frequent chemical application leads to development of pathogenic resistance thus integrated disease management approach was adopted to combine best suitable treatments for the control of cabbage head rot disease. Management practices for disease limiting factors should be adopted such as weed control, day timing and frequency of irrigation, sowing of disease free nursery should also be given proper importance along with chemical control.

There is need to develop resistant varieties of cabbage which can show field resistance against sclerotinia sclerotiorum and a disease predictive model should also be developed by studying important epidemiological factors.

\section{REFERENCES}

Adams, P. and W. Ayers. 1979. Ecology of Sclerotinia species. Phytopathology, 69: 896-899.

Alabouvette, C. and Louvet, J. 1973. Sclerotinia sclerotiorum, Bibliographie Sclerotionnee (Dec. 1971). Information Technology Centre, 31: 726.

Bennett, O. and E. Elliott. 1972. Plant disease incidence on five forage species as affected by North-and South-facing slopes. Plant Disease Reporter, 56: 371-375.

Boland G.J. and Hall R., 1994.Index of plant hosts of Sclerotinia sclerotiorum. Canadian Journal of Plant Pathology, 16: 93-108.

Cubeta, M., B. Cody, Y. Kohli and L. Kohn. 1997. Clonality in Sclerotinia sclerotiorum on infected cabbage in eastern North Carolina. Phytopathology, 87: 1000-1004.

Dickson, M. and R. Petzoldt. 1994. Breeding for resistance to Sclerotinia sclerotiorum in Brassica oleracea. ISHS Brassica Symposium-IX Crucifer Genetics Workshop, 407: 103-108.

Dillard, H. and A. Cobb. 1995. Relationship between leaf injury and colonization of cabbage by Sclerotinia sclerotiorum. Crop Protection, 14: 677-682.

Dillard, H. and J. Hunter. 1986. Association of common ragweed with Sclerotinia rot of cabbage in New York State. Plant disease, 70: 26-28.

Dillard, H. R., R. R. Bellinder and D. A. Shah. 2004. Integrated management of weeds and diseases in a cabbage cropping system. Crop Protection, 23: 163-168.

Fang, Z., Y. Liu, P. Lou and G. Liu. 2005. Current trends in cabbage breeding. Journal of New Seeds, 6: 75-107.

Fayaz, M., A. Ullah Jan and D. Jan. 2014. Quality Elasticity of Vegetable Consumption in Pakistan: A Comparison of Urban and Rural Households. Sarhad Journal of Agriculture, 30: 451-458.

French, R. and D. Schultz. 2009. White mold of cabbage.Texas A\&M University system,College Station,USA.

Govt.of Pakistan, 2016. Integrated Control of insect pests on Canola and other Brassica Oilseed crops in Pakistan, 193.

Hartill, W. F. T., and J. M. Campbell.1973. Control of Sclerotinia in tobacco seedbeds. Plant Disease Reporter, 57: 932-934.

Hoes, J. and H. Huang. 1975. Sclerotinia sclerotiorum: viability and separation of sclerotia from soil. Phytopathology, 65: 1431-1432.

Hou, F., L. Zhao and F. Liu. 2016. Residues and dissipation of chlorothalonil and azoxystrobin in cabbage under field conditions. International Journal of Environmental Analytical Chemistry, 96: 1105-1116.

Hudyncia, J., H. Shew, B. Cody and M. Cubeta. 2000. Evaluation of wounds as a factor to infection of cabbage by ascospores of Sclerotinia sclerotiorum. Plant disease, 84: 316-320.

Jensen, B. D., S. M. Massomo, I. S. Swai, J. Hockenhull 
and S. B. Andersen. 2005. Field evaluation for resistance to the black rot pathogen Xanthomonas campestris pv. campestris in cabbage (Brassica oleracea). European journal of plant pathology, 113: 297-308.

Jiao, Z., J. Deng, G. Li, Z. Zhang and Z. Cai. 2010. Study on the compositional differences between transgenic and non-transgenic papaya (Carica papaya L.). Journal of Food Composition and Analysis, 23: 640-647.

Jones, E. E., N. Rabeendran and A. Stewart. 2014. Biocontrol of Sclerotinia sclerotiorum infection of cabbage by Coniothyrium minitans and Trichoderma spp. Biocontrol Science and Technology, 24: 1363-1382.

Loganathan, M., G. Sible, S. Maruthasalam, D. Saravanakumar, T. Raguchander, M. Sivakumar and R. Samiyappan. 2010. Trichoderma and chitin mixture based bioformulation for the management of head rot (Sclerotinia sclerotiorum (Lib.) deBary)-root-knot (Meloidogyne incognita Kofoid and White; Chitwood) complex diseases of cabbage. Archives of Phytopathology and Plant Protection, 43: 1011-1024.

Mahalingam, T., B. Guruge, K. Somachandra, C. S. Rajapakse and R. N. Attanayake. 2017. First report of white mold caused by Sclerotinia sclerotiorum on cabbage in Sri Lanka. Plant Disease, 101: 249-249.

Mahalingam, T., C. Rajapakse, K. Somachandra and R. Attanayake. 2020. Carbon source dependentanaerobic soil disinfestation (ASD) mitigates the sclerotial germination of Sclerotinia sclerotiorum. Tropical Plant Pathology, 45: 1324.

McLean, D. 1958. Role of dead flower parts in infection of certain crucifers by Sclerotinia sclerotiorum (Lib.) de Bary. Plant Disease Report, 42: 663-666.

Mila, A., A. Carriquiry, J. Zhao and X. Yang. 2003. Impact of management practices on prevalence of soybean Sclerotinia stem rot in the northcentral United States and on farmers' decisions under uncertainty. Plant Disease, 87: 10481058.

Mirza, M. S. and Y. Ahmad. 1988. Cabbage: a new host of Sclerotinia sclerotiorum for Pakistan.
Pandey, A., A. J. Mathew, M. Kamle, R. K. Mishra and P. Kumar. 2012. Efficacy of fungicides for control of white mold (Sclerotinia sclerotiorum Lib.) de Bary in lima bean. Journal of Horticultural Sciences, 7: 114-117.

Pandey, D., N. Tripathi, R. Tripathi and S. Dixit. 1982. Fungitoxic and phytotoxic properties of the essential oil of Hyptis suaveolens/Fungitoxische and phytotoxische Eigenschaften des ätherischen Öis von Hyptis suaveolens. Zeitschrift für Pflanzenkrankheiten und Pflanzenschutz. Journal of Plant Diseases and Protection, 89: 344-349.

Razdan, V. K., and Marium Sabitha.2009. Integrated disease management Concepts and practices. Integrated Pest Management: Innovation-Development Process. Springer, 369-389.

Saharan, G. S. and N. Mehta. 2008. Sclerotinia diseases of crop plants: biology, ecology and disease management. Springer Science \& Business Media, 1-481.

Sanogo, S., P. Lujan and D. Baucom. 2015. First report of Sclerotinia sclerotiorum on cabbage in New Mexico. Plant Disease, 99: 891.

Sherf, A. F. and A. A. MacNab. 1986. Vegetable diseases and their control. John Wiley \& Sons, 23.

Singh MP, Tripathi HS (1993) Effect of storage temperatures on the survival of Botrytis cinerea in chickpea seeds. Indian Journal of Mycology and Plant Pathology, 23: 177-179.

Singh, B., S. Sharma and B. Singh. 2010. Antioxidant enzymes in cabbage: variability and inheritance of superoxide dismutase, peroxidase and catalase. Scientia Horticulturae, 124: 9-13.

Sugha, 1999. Efficacy of carbendazim granules against Sclerotinia sclerotiorum of pea (Pisum sativum), cabbage (Brassica oleracea var capitata) and cauliflower (Brassica oleracea var botrytis. Indian Journal of Agricultural Sciences, 69: 302-303.

Tores, J. and R. Moreno. 1991. Sclerotinia sclerotiorum, epidemiological factors affecting infection of greenhouse aubergine crops. Journal of Phytopathology, 132: 65-74. 
Turkington, T. and R. Morrall. 1993. Use of petal infestation to forecast Sclerotinia stem rot of canola: the influence of inoculum variation over the flowering period and canopy density. Phytopathology, 83: 682-689.

Wang, J.P., Y.P. Xu, X.P. Zang, S.S. Li and X.Z. Cai. 2016. Sclerotinia sclerotiorum virulence is affected by mycelial age via reduction in oxalate biosynthesis. Journal of Integrative
Agriculture, 15: 1034-1045.

Willetts H.J. and Wong A.L. 1980. The biology of Sclerotinia sclerotiorum Strifoliorum and $S$. minor with emphasis on specific nomenclature. The Botanical Review, 46: 101-165.

Young, C. and C. Werner. 2012. Infection routes for Sclerotinia sclerotiorum in apetalous and fully petalled winter oilseed rape. Plant pathology, 61: 730-738.

\section{Contribution of Authors:}

Muhammad U. Yasin $\quad$ : Conduct research and wrote manuscript

Saba Saeed

: Provide technical assistance in conducting research

Saima Naseer

: Review manuscript 